\title{
2.5-D Earth Crust Density Structure Modeling of the Central Part of Cameroon Using Gravity Data
}

\author{
Françoise Martine Enyegue à Nyam ${ }^{1 *}$, Albert Eyiké Yomba², Alain Rodrigue Nzeuga ${ }^{1 *}$, \\ Alix Stanislas Soh ${ }^{1}$ \\ ${ }^{1}$ Department of Physics, Faculty of Science, University of Yaounde I, Yaounde, Cameroon \\ ${ }^{2}$ Faculty of Science University of Douala, Head of the Watch Technologic Unit Ministry of Scientific Research and Innovation, \\ Yaounde, Cameroon \\ Email: ^francem2019@yahoo.com, *alainzeuga@yahoo.fr
}

How to cite this paper: à Nyam, F.M.E. Yomba, A.E., Nzeuga, A.R. and Soh, A.S. (2020) 2.5-D Earth Crust Density Structure Modeling of the Central Part of Cameroon Using Gravity Data. Open Journal of Earthquake Research, 9, 289-306.

https://doi.org/10.4236/ojer.2020.93017

Received: January 15, 2020

Accepted: May 24, 2020

Published: May 27, 2020

Copyright (c) 2020 by author(s) and Scientific Research Publishing Inc. This work is licensed under the Creative Commons Attribution International License (CC BY 4.0).

http://creativecommons.org/licenses/by/4.0/

\section{Open Access}

\begin{abstract}
The knowledge of areas of high and low geophysical densities is of paramount importance to better understand the geodynamic, tectonic and geomorphologic evolution of the earth. Several geophysical methods have been developed to achieve this, including a $2.5 \mathrm{D}$ modeling from gravity data, which is the approach used in this work and whose aim is to highlight the causative geological structures of these contrasts in the central part of Cameroon. This zone extends between latitudes $3^{\circ}$ and $7^{\circ}$ North and longitudes $11^{\circ}$ and $16^{\circ}$ East. Several filters were applied to the gravimetric and topographic data using the Oasis Montaj software from geosoft in order to develop the different anomaly maps and Grav2dc in order to develop the different geological models of the subsoil. In the final analysis, it appears that this part of Cameroon suggests the presence of granitic rocks and sedimentary rocks whose density contrasts vary between -0.19 and $-0.205 \mathrm{~g} / \mathrm{cm}^{3}$ observed in the localities of Banyo, Ngaoundere and Abong-Mbang. We also observe the presence of gneiss and volcanic rocks of contrast density varying between 0.0522 to $0.0534 \mathrm{~g} / \mathrm{cm}^{3}$ in the locality of Tibati, and granitic intrusions in addition to basic rocks of contrast density varying between 0.285 at $0.29 \mathrm{~g} / \mathrm{cm}^{3}$ in the localities of Yoko, Bertoua and Belabo.
\end{abstract}

\section{Keywords}

Gravity Anomaly, Modeling, Volcanic Intrusions

\section{Introduction}

The Cameroon Pan-African chain contains rocks of different nature in its base- 
ment capable of creating gravity anomalies, which can be observed from the surface of the Earth. This chain encompasses central Cameroon which is our study area. Central Cameroon has a complex tectonics marked by the presence of large Precambrian faults, known as the Cameroon Shear Zone (Ngako et al.) [1], whose reactivation controlled the establishment of the sedimentary basins of the Mbere and Djerem, and the development of intraplate volcanism along the Cameroon Line. This region has already been the subject of several geophysical studies, the main results of which suggest the presence of a thin crust (Dorbath et al. [2]; Poudjom [3]), intruder of non-flush igneous rocks, of a basic nature, which would have been implemented thanks to the reactivation of the Cameroon Shear Center (Noutchogwe [4]; Kande [5]). The lithosphere would also be reduced following a rise in the asthenospheric fluid in a context of incipient rift (Poudjom [3]; Poudjom et al. [6]). The work of (Noutchogwe [4]) suspects the presence of basaltic rocks, gneiss, granite and sediments in this area precisely in Adamawa.

From this work, we ask ourselves what could be the nature of the rocks which structure this chain and more precisely our study site. Our work essentially proposes 2.5-D type basement models which present the different density contrasts of the bodies which contribute to the structuring of the whole region. To do this, we used the separation method to produce gravity maps and models. In the final analysis, we noticed that in the localities of Banyo, Ngaoundere and Abong-Mbang, the gravimetric anomalies observed suggest the presence of granitic and sedimentary rocks whose density contrast varies between -0.19 and $-0.205 \mathrm{~g} / \mathrm{cm}^{3}$. Also, in the locality of Tibati, we observed the presence of gneiss and volcanic rocks with a density contrast varying between 0.0522 and $0.0534 \mathrm{~g} / \mathrm{cm}^{3}$ and in the localities of Yoko, Bertoua and Belabo, granitic and basic intrusions density contrast vary between 0.285 to $0.29 \mathrm{~g} / \mathrm{cm}^{3}$.

\section{Geology and Tectonics of the Area}

The study area is bounded to the south by the $3^{\circ} \mathrm{N}$ parallel, to the north by the $7^{\circ} \mathrm{N}$ parallel, to the west by the $11^{\circ} \mathrm{E}$ meridian border with Nigeria, to the east by the $17^{\circ}$ meridian $\mathrm{E}$ (Figure 1). It covers four regions, including a part of the South, East, Center and Adamawa, the main cities of which are: Yaounde, Ngaoundere and Bertoua.

This area has been the subject of several geological and geophysical studies, the main results of which are as follows: After recognition surveys carried out in central Cameroon in the 1950 (Guiraudie [8]; Lasserre [9]), the results of which are compiled in the geological map of the United Republic of Cameroon, more recent data have been obtained following work carried out on the central domain of the Pan-African chain of Cameroon (Soba [10]; Ngako et al. [1]; Ngako [11]; Nzenti et al. [12]; Ngnotué et al. [13]; Toteu et al. [14]; Kapajika [15]) and the Cameroon Line in Adamawa (Temdjim [16]; Dautria and Girod [17], Nono et al. [18], Menard et al. [19]). These detailed studies generally applied different 


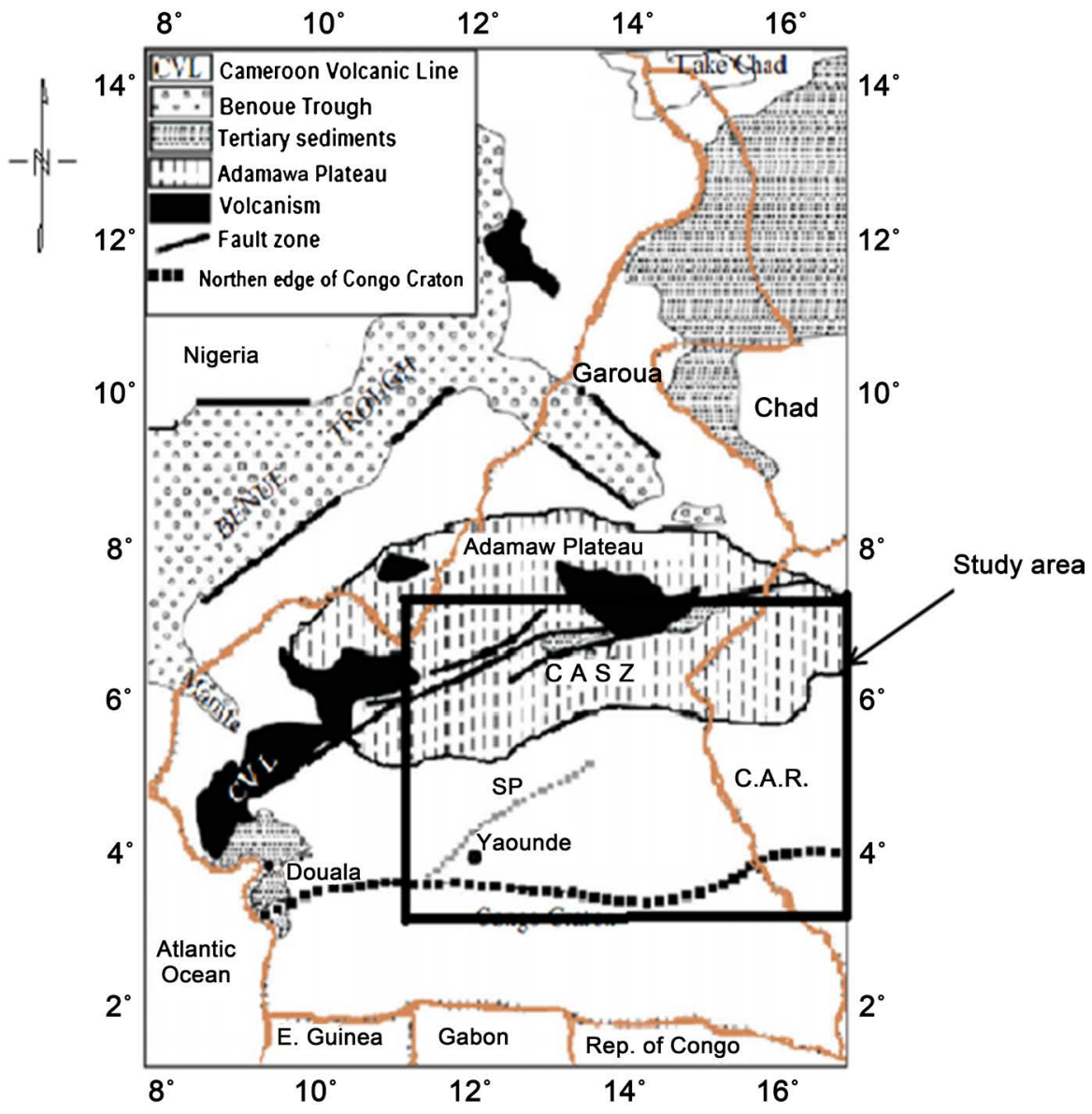

Figure 1. Study area on a geological map of Cameroon with major structural units (Ngatchou et al. [7]).

methods of approach: geochronology, microtectonics, study of metamorphism, petrology, geochemistry and volcanology.

The structural units of Cameroon are mainly characterized by the Cameroon Volcanic Line (CVL), the Adamawa Plateau and the Central African Shear Zone (CASZ).

- CVL is a major tectonic feature of West Africa, about $1600 \mathrm{~km}$ long. Its continental segment includes Mont. Cameroon (4095 m), Mt. Manengouba (2420 m), Mont. Bamboutos (2670 m) and Mont Oku (3011 m) (Ateba et al. [20]). The CVL is formed at the base of Pan-African rocks made up mainly of schists and gneiss intersected by granites and diorites (Déruelle et al. [21]);

- The Adamawa Plateau is an area that was raised after the Cretaceous activities on the northeast side of Cameroon (Nnange et al. [22]). It has a sedimentary section with a series of small synclines;

- The CASZ is another characteristic tectonic zone extending from Darfur in Sudan to the Adamawa Plateau (Dorbath et al. [23]). It is characterized by high density crust rocks (Ayonghe [24]). Its extension to the Southwest is known as the Foumban Shear Zone (FSZ). The lithosphere is thin under the CASZ with a rise in the asthenosphere (Plomerova et al. [25]). The Sanaga 
Fault (SF) is another dextral shear zone parallel to the CASZ (Dumort [26]). The border between the Pan-African belt and the Congo Craton (CC) occupies part of southern Cameroon and progresses towards the north of the Central African Republic. The CC consists mainly of Archean rocks with certain resedimented materials formed in the Paleoproterozoic.

The Pan-African chain is the area that lies between the West African craton in the North West and the Congo craton in the South. Rocks such as: syenite, post and syn-tectonic granite with an extended part in the Center, East and Adamawa regions. The gneiss and migmatites spread through all the regions of the study area, mica schist and volcanic schist spread around the Center, South and the East regions, making this area to be amongst those that have been subjected to Pan-African tectonics, whose geochronological ages show a rejuvenation of 500 $600 \mathrm{Ma}$. The Djerem and Mbere basins belong to the central geodynamic domain of the north equatorial pan-African chain in Cameroon (Nzenti et al. [27]) or the Adamawa-Yaounde domain of the pan-African chain (Toteu et al. [28]). These basins are located on the southern margin of the Adamawa plateau or the Cameroon Shear Center (CSC), which seems to mark the paleogeographic limit between a northern domain with characteristics of an active margin (Ngako [11]) and a predominantly continental southern domain (Nzenti et al. [27]). They are located between Longitudes $6^{\circ} 20^{\prime} \mathrm{N}$ and $7^{\circ} 08^{\prime} \mathrm{N}$ and Latitudes $12^{\circ} 14^{\prime} \mathrm{E}$ and $15^{\circ} 07^{\prime} \mathrm{E}$.

The study site shows traces of the various tectonic events which marked the Pan-African geological period. Geochronological work allows the evolution of the northern edge of the Congo craton to be split into two major tectonic episodes:

- The Archean episode which begins at $3.1 \mathrm{Ga}$ and corresponds to a phase of distension with the formation of marine or continental basins filled with volcano-sedimentary materials, injected thereafter with basic rocks (magmatic rocks poor in silicon, with the absence of quartz and rich in Magnesium, iron and Calcium). This distension phase is followed by a compressive phase $(2.9$ to $2.6 \mathrm{Ga})$ associated with an abundant charnockitic plutonism (comprising of magmatic rocks with traces of granite or whitish to greenish gneissic granite);

- The lower Proterozoic episode starts from 2.4 Ga with fractures and thermal events. Warming favours a reshufflement of Archean formations. A high degree metamorphism dated to $2.05 \mathrm{Ga}$ accompanies the deformation which is gaining momentum in the Nyong unit. The Nyong unit is the result of the collision between the cratons of the Congo-Sao Francisco in the Lower Proterozoic.

In the Upper Proterozoic, the Congo craton is formed by a network of intra-cratonic ditches. The upper Proterozoic formations outcropping in southeastern Cameroon's Dja series, are superimposed in the collapsed areas of the craton, masked by recent deposits from the equatorial forest of the Congolese 
basin.

These different tectonic phases led to the establishment of the structural units of the region with a certain number of lines representing density discontinuities whose directions are: NS, NE-SW, EW and NW-SE. The predominant direction for large lineaments is NE-SW. The major lineaments associated with the faults are: the Kribi-Edéa faults, the Ambam faults, the Bipindi-Yaounde faults and the Pouma-Yaounde fault. Adamawa Pan-African faults are transgressive, controlling the placement of many so-called "syn-tectonic" granites (Ngako et al. [29]; Nzenti et al. [12]). The Cretaceous region is marked by extensive tectonics in relation to the opening of the South Atlantic (Ngangom [30]; Popoff [31]). Pan-African faults replay in dextral shear, giving rise to the Mbere ditch and the Djerem basin (Cornacchia and Dars [32]; Dumort [26]; Dumort [33]). In the Upper Cretaceous and Tertiary zones, volcanic activity affects the Adamawa plateau, volcanic products being mostly basalts and andesites (Temdjim and Tchoua [34]).

\section{Gravimetric and Topographic Data and Methodology}

\subsection{Gravimetric and Topographic Data}

The gravimetric data used in this study come from the Earth Gravitational Model, EGM08. These satellite data have been corrected for long wavelengths (greater than $300 \mathrm{~km}$ ) of anomalies. The topographic data were obtained from the model of the structure of the earth's crust in the area modeled by Eyike and Ebbing [35].

\subsection{Methodology}

We used the separation method in this work. To avoid the subjectivity inherent in graphic methods, we opted for the least-square analytical method. The principle consists of constructing a polynomial equation of high order, which generates an analytical surface and adapts to an experimental surface by the method of least squares. This analytical surface represents the region, and the important variations of variable compared in this regional make it possible to separate the masses which can correspond more or less to buried sources. Let $G\left(x_{i}, y_{i}\right)$ be the value of the Bouguer anomaly at point $P\left(x_{i}, y_{i}\right)$. It is a question of calculating the values $\operatorname{REG}\left(x_{i}, y_{i}\right)$ and $\operatorname{RES}\left(x_{i}, y_{i}\right)$ by a suitable choice of the polynomial $F\left(x_{i}, y_{i}\right)$ of order $\mathrm{N}$ which generates an analytical surface, $\operatorname{REG}\left(x_{i}, y_{i}\right)$ most possibly closed to the experimental surface $g\left(x_{i}, y_{i}\right)$. This polynomial can be written in the form (Radhakrishhna and Krishnamacharyulu [36]):

$$
F\left(x_{i}, y_{i}\right)=B_{1}+\sum_{j=1}^{N} \sum_{l=0}^{j} B_{m} A_{j l}\left(x_{i}, y_{i}\right)
$$

where $N$ is the order of the polynomial and $B_{m}$ are the coefficients to be determined.

Equation (6) can also be written in the form: 


$$
F\left(x_{i}, y_{i}\right)=\sum_{m} B_{m} A_{m}\left(x_{i}, y_{i}\right)
$$

where

$$
A_{m}\left(x_{i}, y_{i}\right)=x_{i}^{l} y_{i}^{(j-l)}
$$

and

$$
m=\frac{j(j+3)}{2}-l+1
$$

For a fixed value of $\mathrm{N}$, we have $\frac{(N+1)(N+2)}{2}$ coefficients.

We denote by

$$
\varepsilon_{i}=G\left(x_{i}, y_{i}\right)-F\left(x_{i}, y_{i}\right),
$$

the difference between the homologous points of the experimental and analytical surfaces respectively and by $N_{0}$ the number of stations $P_{i}$ where the Bouguer anomaly is known. Adjusting the surfaces consists of minimizing the quadratic deviation:

$$
E=\sum_{j=1}^{N_{0}} \varepsilon^{2} \text { soit } \frac{\partial E}{\partial B_{k}}=0
$$

This leads to:

$$
\sum_{j=1}^{N_{0}}\left[G\left(x_{i}, y_{i}\right)-F\left(x_{i}, y_{i}\right)\right] A_{k}\left(x_{i}, y_{i}\right)=0
$$

Taking into account (4-2), we finally have:

$$
\sum_{j=1}^{N_{0}} G\left(x_{i}, y_{i}\right) A_{k}\left(x_{i}, y_{i}\right)=\sum_{m=1}^{\frac{(N+1)(N+2)}{2}} B_{m} \sum_{j=1}^{N_{0}} A_{k}\left(x_{i}, y_{i}\right) A_{m}\left(x_{i}, y_{i}\right)
$$

We then obtain a system of equations with unknowns. The unknowns being the coefficients $B_{m}$ of the polynomial $F\left(x_{i}, y_{i}\right)$ of order $N$. Once the coefficients have been determined, we calculate the regional analytical anomaly, $\operatorname{REG}\left(x_{i}, y_{i}\right)=F\left(x_{i}, y_{i}\right)$ and we deduce the residual:

$$
\operatorname{RES}\left(x_{i}, y_{i}\right)=G\left(x_{i}, y_{i}\right)-F\left(x_{i}, y_{i}\right)
$$

The calculations were carried out using the FORTRAN program 77 "POLYFIT" (Radhakrishna and Krishnamacharyulu [36]), which generates the polynomial equation of order $\mathrm{N}$, establishes and solves the system of linear equations to determine the coefficients $B_{m}$ of the polynomial, then gives the values of the regional and residual anomalies at each point where the Bouguer anomaly is defined.

Considering gravimetric modeling, Talwani and Ewing [37] established the formula for calculating the gravity anomaly generated by a 3-D type body on a computer. The method used consists of cutting the solid into infinitely thin blades and summing the gravitational effects of the different blades, and then assimilated to polygons with $\mathrm{n}$ sides, $\mathrm{n}$ being as large as possible so that the contour of each blade is best superimposed on the polygon. The geological terrain models were produced from the isostatic residual anomaly map according to 
eleven (11) profiles that we selected. These models were made on each of the profiles using the Gav2dc software in which we varied the physical parameters such as: the source depth, the density contrast as well as the width of the body to be modeled. Upon completion, we can have an idea of the depth of the different sources of gravity anomalies identified and the value of the corresponding densities. To constrain the interpretation, we proceeded to a two-layer modeling, taking into account our knowledge of the geology of the region. The density contrasts were chosen by referring to the ranges of average rock densities existing in the literature (Darly [38]; Sydney and Clark [39]; Telford et al. [40]).

\section{Results and Discussions}

\subsection{Topographic Map of the Study Area}

A topographic map is a map on a reduced scale representing the relief determined by altimetry of a geographic region in a precise and detailed manner on a horizontal plane. This was represented in 2-D (Figure 2) and highlights the multiple variations in altitude of the area. This altitude is very important in the cities of Bankim, Tibati and Meiganga in the Adamawa region and extends towards Garoua Boulai where the values of the altitude are higher with peaks reaching $1300.5 \mathrm{~m}$. At the upper end of the map, precisely in the cities of Tignere, Ngoundere, Djohong and Yokaduma, we observe a low altitude reaching up to $364.7 \mathrm{~m}$. These low altitudes are also observed in the cities of Bafia, Belabo, Yoko, Bertoua and Nang-Eboko.

\subsection{Bouguer Anomaly Map}

The simple Bouguer anomaly map shown in Figure 3 was produced using the

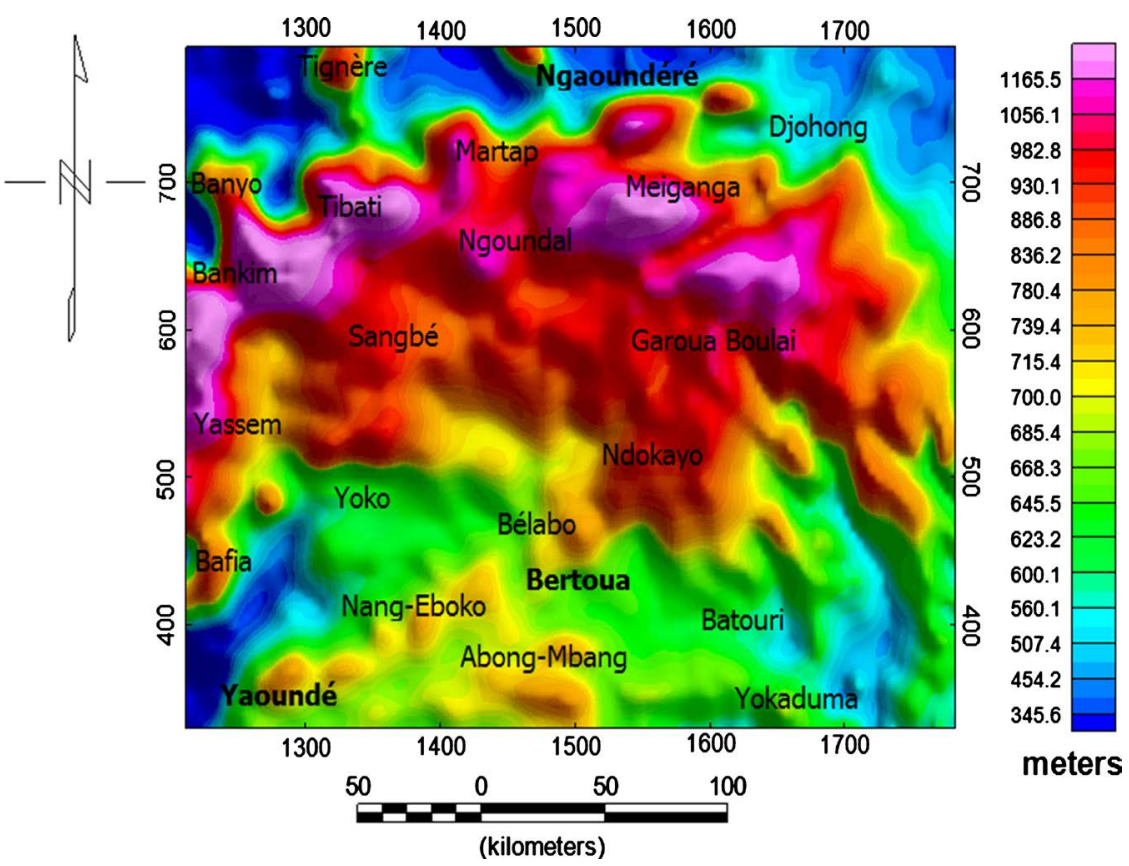

Figure 2. Topographic map representing the altitude variation of the study area. 


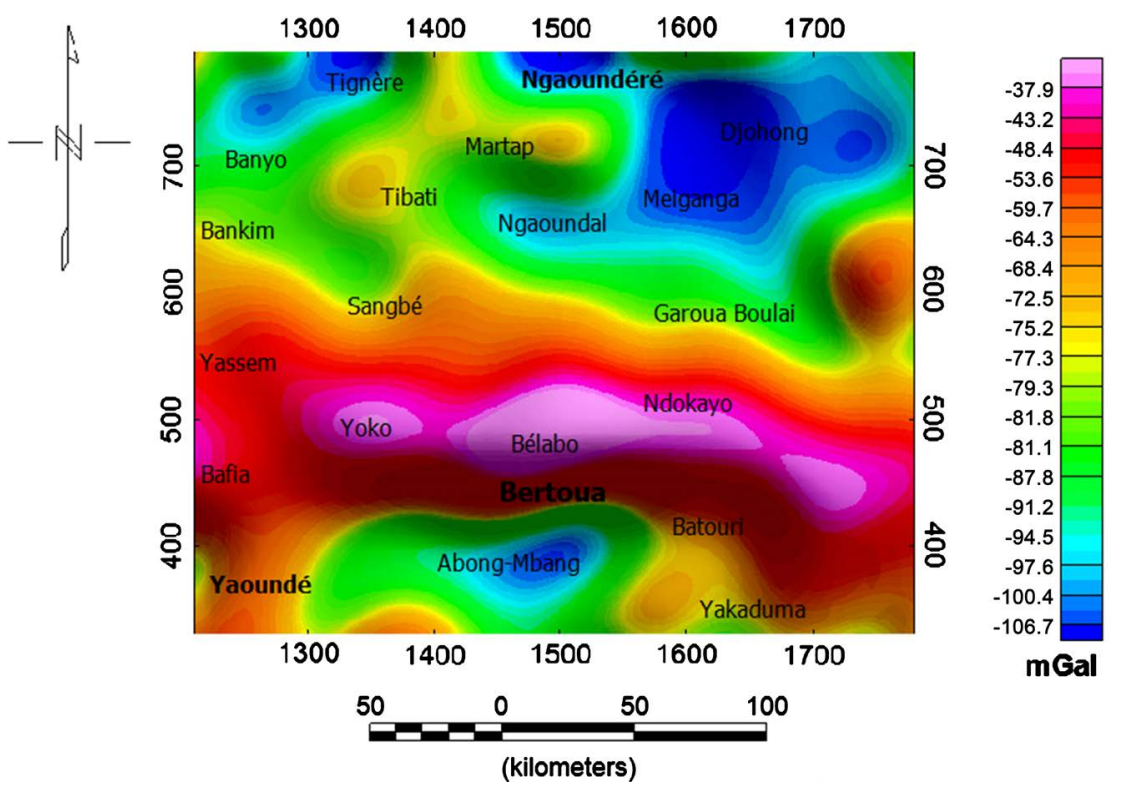

Figure 3. Bouguer Anomaly map of the study area.

Oasis Montaj software from Géosoft. This map is the result of the superimposition of the effects of geological structures located at varying depths (surface, medium and deep). It provides information on the discontinuities present in the subsoil and presents on the one hand, areas of heavy anomalies (anomalies above the average which is $-79.7 \mathrm{mGal}$ ), and on the other hand, areas of slight anomalies (anomalies below average), sometimes separated from the first by more or less significant horizontal gradients characterized by the tightening of the iso-anomalous lines.

A comparison of this map with the geological map indicates that the negative anomalies observed around the towns of Tignere, Djohong, Ngaoundere and Abong-Mbang, are entirely located in shales, quartzites and in sedimentary rocks, while the negative anomalies around cities Bafia, Yoko, Belabo and Ndokayo suggest numerous intrusions of igneous rocks into the crust, testifying to intense magmatic activity. The origin of these anomalies could be attributed to the effects of a plate suture of the linear or filiform iso-anomalies reflecting a variation in the density of the underlying rocks; they materialize structures ranging from shallow to great depths. This map shows that there are two main characteristics of the region: the northern (northern) margin and the western (western) margin of the Congo craton.

A comparison between the negative anomalies of long wavelengths observed and the topography of the Adamawa plateau characterized by an average altitude of $1100 \mathrm{~m}$ allows us to raise several hypotheses: the first on the origin of this anomaly is isostatic compensation, which would have been affected by a sinking of the crust in the heavier upper mantle. This shows that the thickness of the crust is normal ( $33 \mathrm{~km})$ in cities such as Sangbe, Yoko, Bankim, Belabo, Ndikayon and Bafia, and more reduced $(23 \mathrm{~km})$ when progressing towards cities such as Tignère, Banyo, Tibati, Djohong, Meiganga, Abong-Mbang and Ngaoundéré; the 
second hypothesis is that of an asthenospheric ascent which results in a thin lithosphere around the cities of Tignere, Banyo, Tibati, Djohong, Meiganga, Abong-Mbang and Ngaoundere. The great negative anomaly of Adamawa was therefore attributed to the resulting bombing while the zone of positive maxima, narrower and centered around the cities of Yoko, Ndikayon and Belabo was attributed on one hand to the thin crust and on the other hand to the existence of non-flush magmatic pockets.

\subsection{Isostatic Residual Map}

The isostatic anomaly is obtained using a complex calculation process. It consists first of all in considering the Airy-Heisanen compensation model while taking into account parameters such as the density of the crust, the density contrast and the density of the mantle so the values are respectively $2.67,0.66$ and $3.27 \mathrm{~g} / \mathrm{cm}^{3}$, then calculate the crustal root thickness of compensation followed by the topographic compensation effect at each of the measurement points. We deduced the isostatic anomaly by applying these corrections to the Bouguer anomaly; its residual and regional components are obtained using a separation method.

Figure 4 represents the map of the isostatic residual anomalies of the study area. A general observation of this reveals a fairly diversified structure in which the directions of the anomalies vary and also show important details which are not visible on the Bouguer anomaly map. Thus, the elimination of the regional effects makes it possible to clearly distinguish the negative anomalies from the positive anomalies of the gradient zones.

The positive anomalies observed around the cities of Yassem, Yoko, Belabo, Ndokayo, Bertoua, Bafia, Bangbe, Bankim, Garoua Boulai, Tibati and Martap are lengthened in the structural direction W-E. These would have a mantle origin

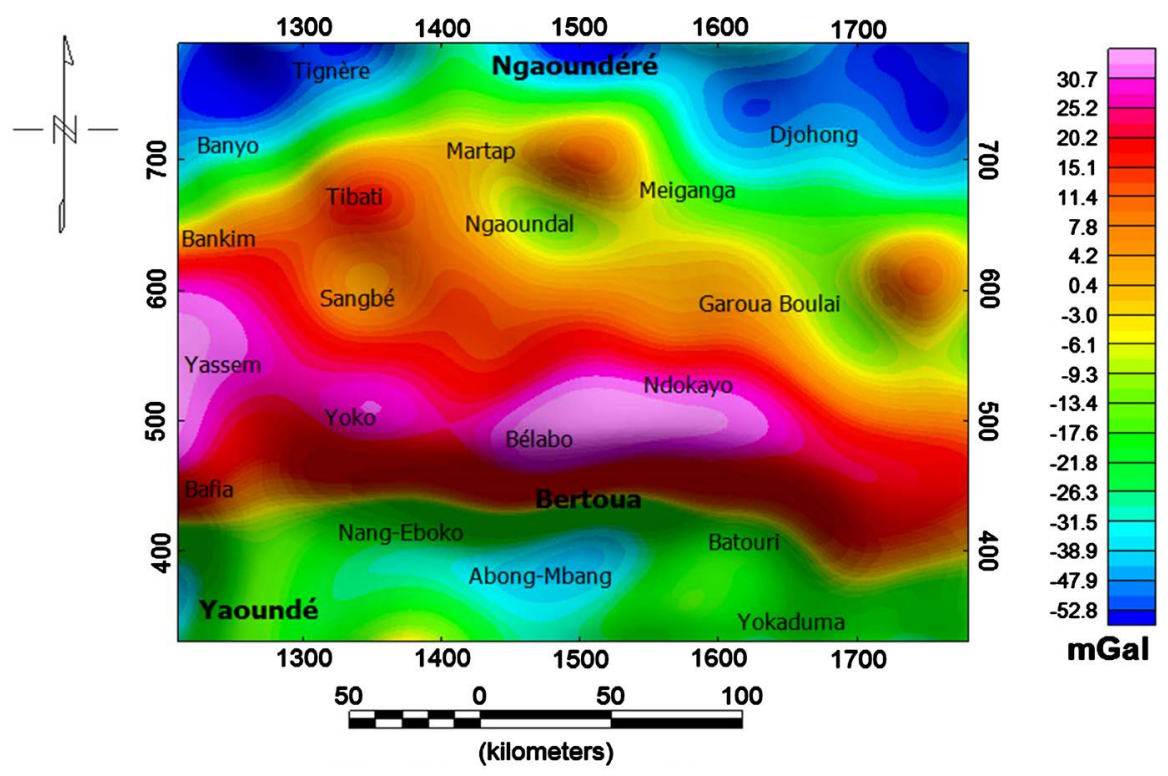

Figure 4. Isostatic residual anomalies map of the study area. 
and would characterize an uplifting of the pan-African base in this part of the zone and mark the transition and the limit between the craton of Congo and the pan-African chain of Central Africa. The negative anomalies observed around the localities of Banyo, Tignere, Abong-Mbang, Djohong and Ngaoundere could be justified by the collapse of the basement or a slight intrusion into the crust. The zones of positive anomalies are separated from the zones of negative anomalies by the gradient zones. These are areas that mark the sudden variations in the values of anomalies characterizing tectonic accidents or intrusions ranging from shallow to great depths.

\subsection{Choice of Profiles}

In this work, we have chosen 11 profiles on the residual anomalies map in the $\mathrm{N}-\mathrm{S}$ direction, perpendicular to the main direction of the network of isogal lines (Figure 5). These profiles are separated from each other by a distance of $50 \mathrm{~km}$, and each has a lenght of $500 \mathrm{~km}$.

\subsection{Modeling}

\section{- Geological model according to the profile $P_{1}$.}

Figure 6 represents the geological model of the subsoil of the study area traced according to the $\mathrm{P}_{1}$ profile. This model justifies the presence of intrusions of volcanic rocks with density contrast of $0.295 \mathrm{~g} / \mathrm{cm}^{3}$ in sedimentary rocks of density contrast of $-0.195 \mathrm{~g} / \mathrm{cm}^{3}$.

\section{- Geological Models using the profiles P2, P3 and P4.}

The geological models using the profiles $\mathrm{P}_{2}, \mathrm{P}_{3}$ and $\mathrm{P}_{4}$ are represented in Figure 7. These models reveal the presence of gneissic formations (density contrast $0.055 ; 0.0600 \mathrm{~g} / \mathrm{cm}^{3}$ ) and granito-basaltic formations (density contrast 0.295

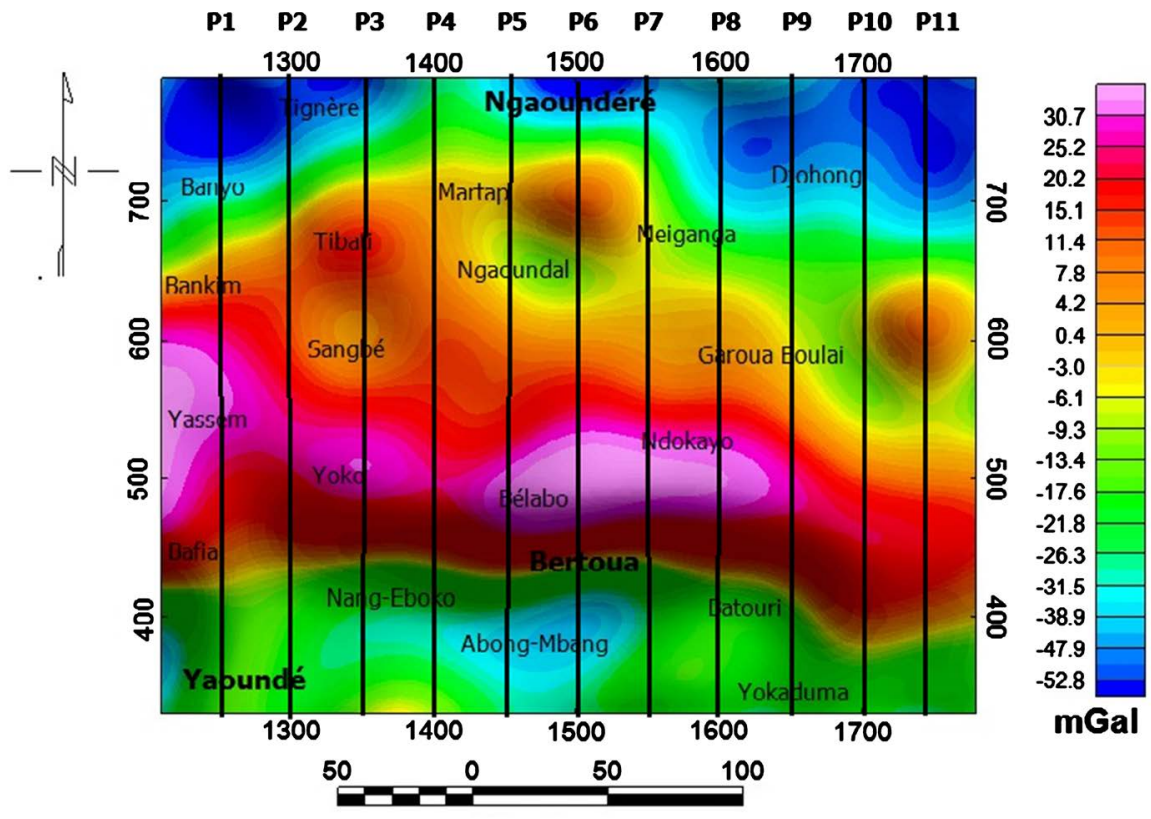

Figure 5. Profile positions $\mathrm{P}_{1}$ to $\mathrm{P}_{11}$ on the Residual anomaly map. 


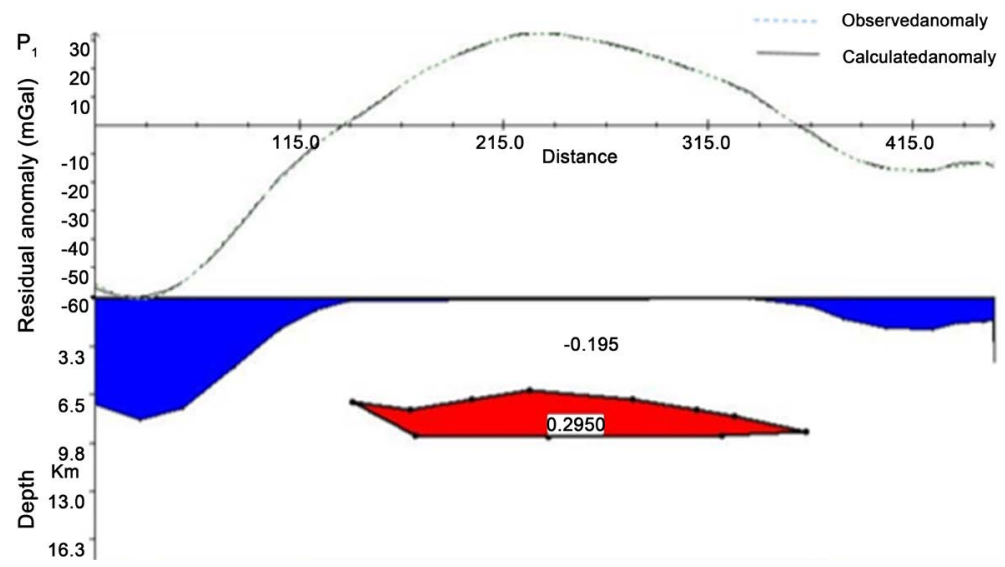

Figure 6. Geological models using the profile $\mathrm{P}_{1}$.
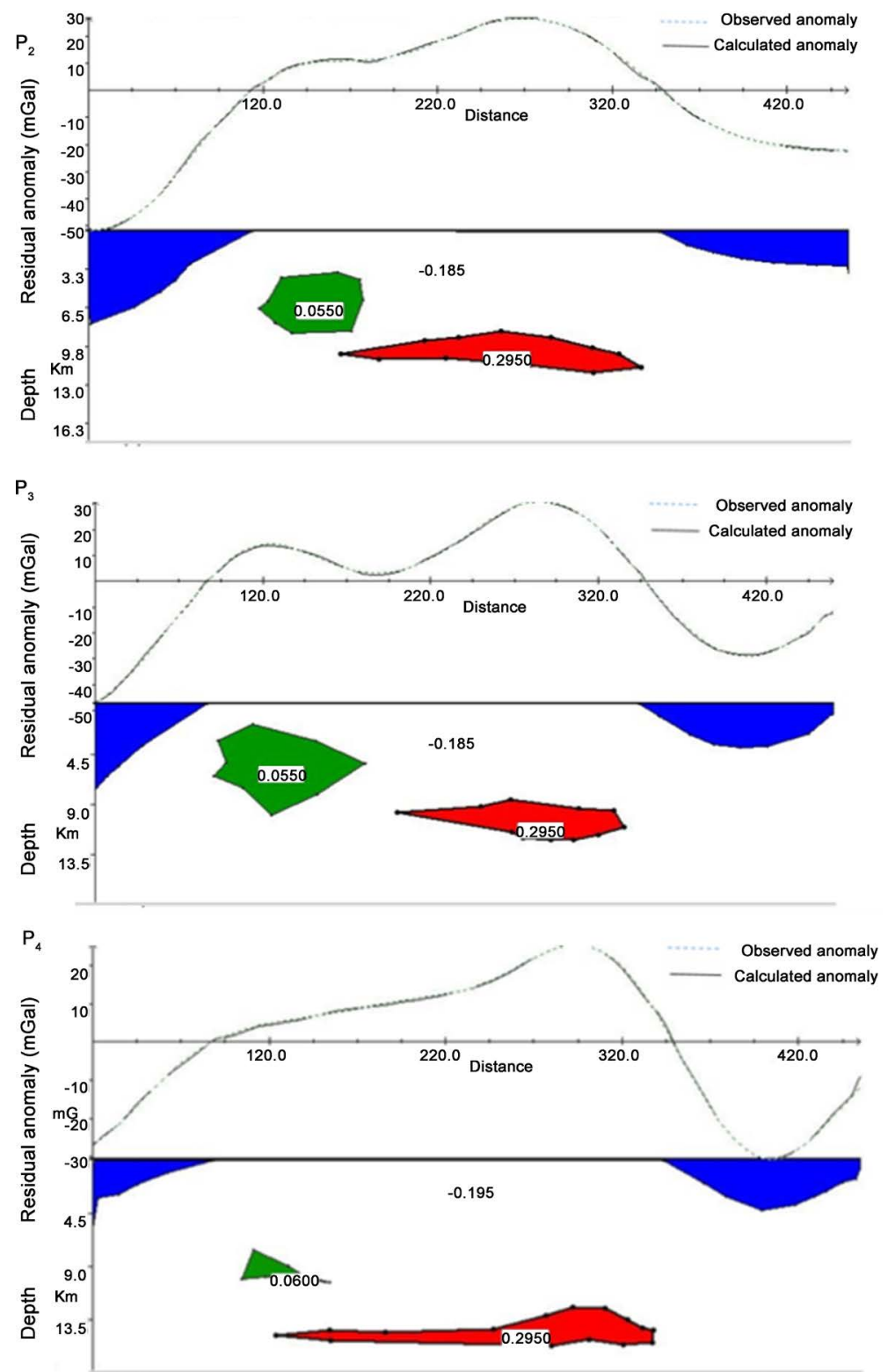

Figure 7. Geological models using the profiles $\mathrm{P}_{2}, \mathrm{P}_{3}$ and $\mathrm{P}_{4}$. 
$\left.\mathrm{g} / \mathrm{cm}^{3}\right)$ in sediments.

\section{- Geological models using the profiles $P_{5}$ and $P_{6}$.}

These models represented in Figure 8 reveal the presence of intrusions of basaltic and metamorphic rocks in sedimentary rocks.

\section{- Geological models from the profiles $P_{7}, P_{8}, P_{9}, P_{10}$ and $P_{11}$.}

Figure 9 represents the geological models of subsoil calculated according to profiles $\mathrm{P}_{7}, \mathrm{P}_{8}, \mathrm{P}_{9}, \mathrm{P}_{10}$ and $\mathrm{P}_{11}$. These models only reveal the presence of intrusions of volcanic rocks in the sediments, except for the $\mathrm{P}_{11}$ profile where we also observe an intrusion of metamorphic rock which would be gneiss.

\subsection{Discussion}

The problem encountered in this work lies in the fact that gravimetric data are static. However, the analysis of the gravity anomaly maps and the interpretation of the gravity profiles aimed on one hand to highlight the geodynamics of the Congo craton and to determine the nature of the underlying rocks of our study area, and on the other hand to highlight the structural features of its southern, central, eastern and Adamawa margins.

These results can be summarized as follows:

- The zones of negative anomalies observed in the center down to -106.2 mGals could be linked to the gravimetric effect of the intrusion of light

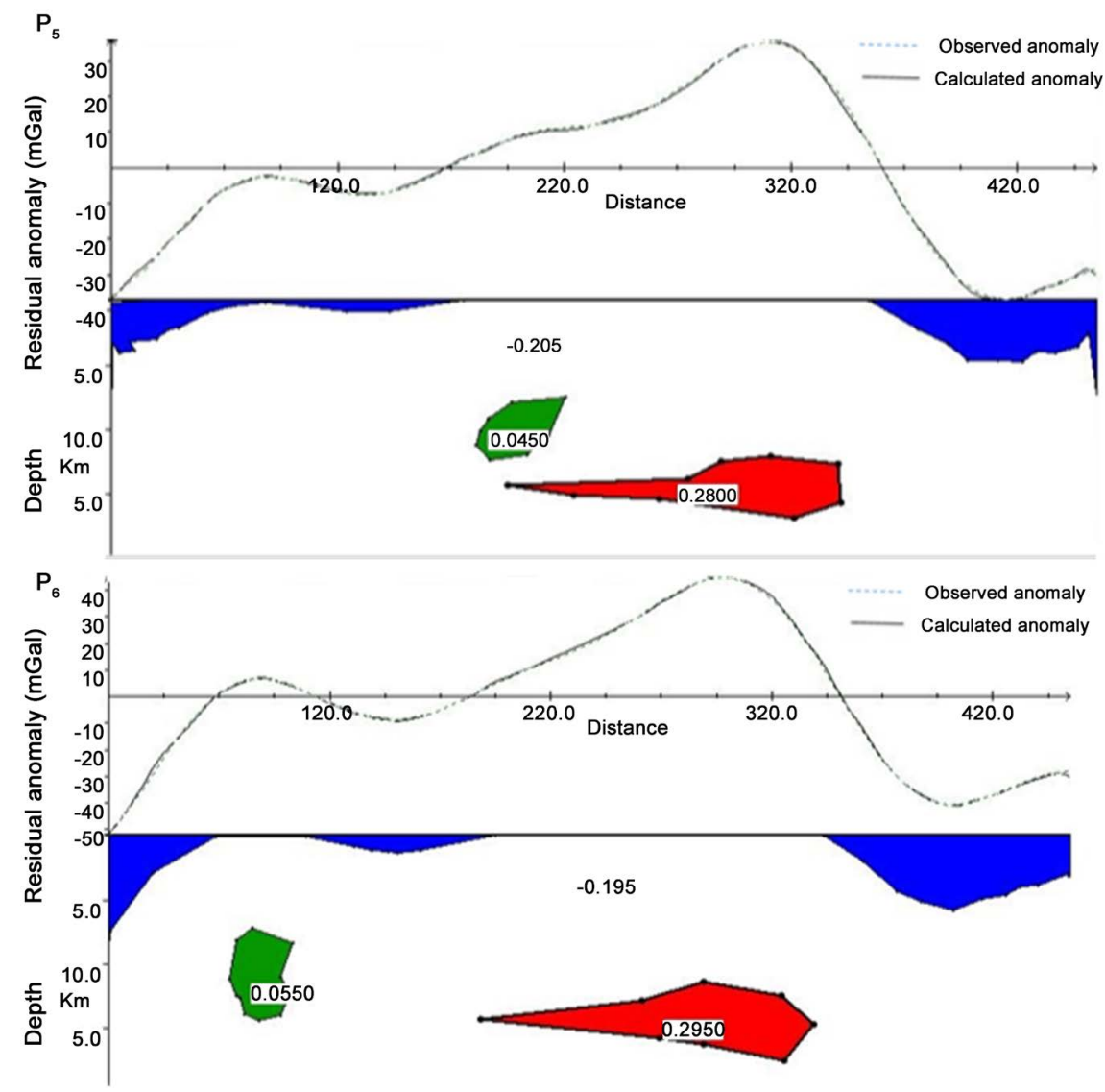

Figure 8. Geological models using the profiles $\mathrm{P}_{5}$ and $\mathrm{P}_{6}$. 


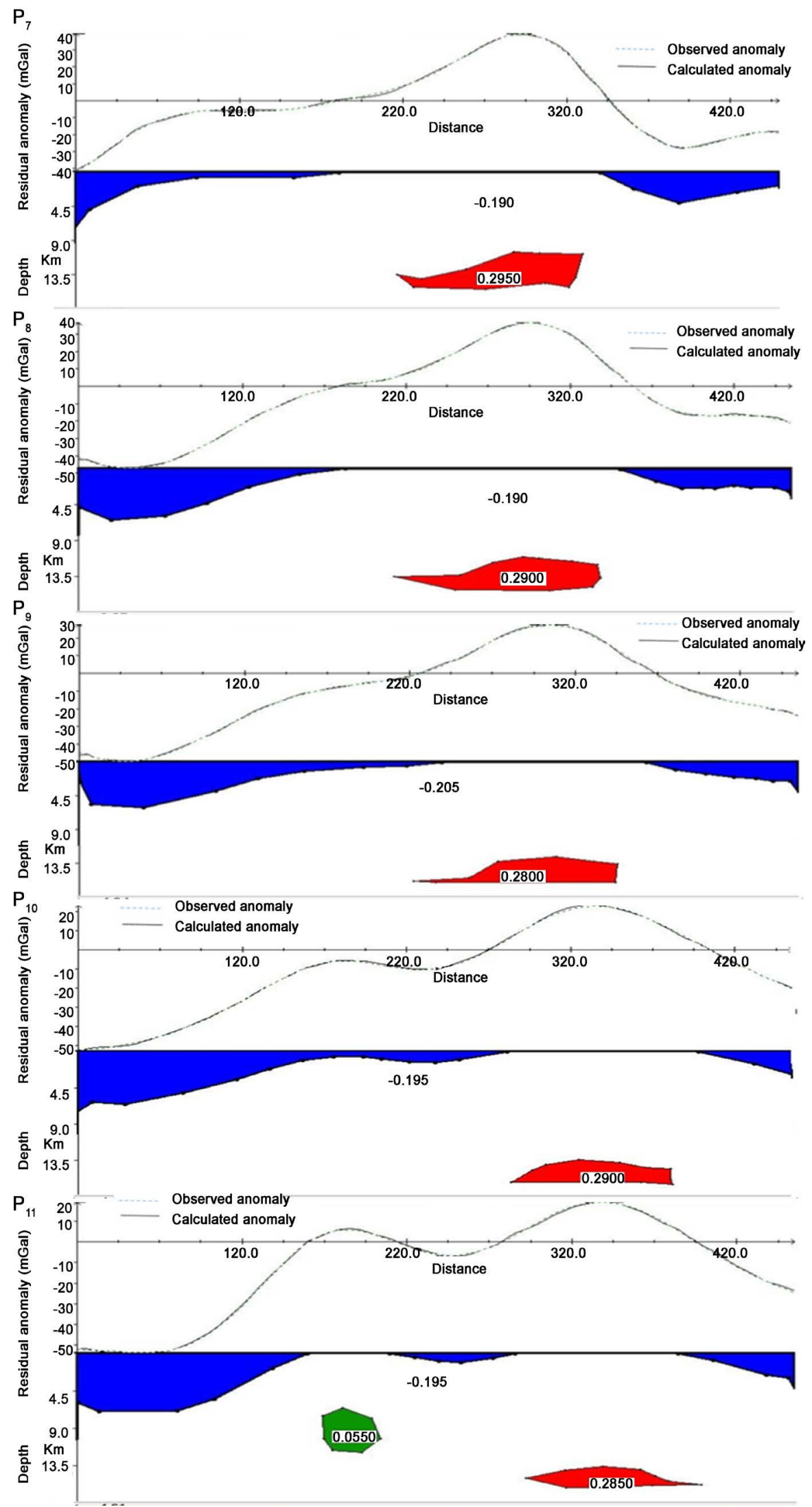

Figure 9. Geological models from the profiles $\mathrm{P}_{7}, \mathrm{P}_{8}, \mathrm{P}_{9}, \mathrm{P}_{10}$ et $\mathrm{P}_{11}$. 
granites comparable to sediments with a negative density contrast compared to the crust. This intrusion could probably be responsible for the vast anomaly observed in the center of the region and could be a consequence of the collapse of the basement of the region;

- Analysis of the Bouguer residual anomaly map and its profiles along the N-S directions show areas of negative anomalies that could be a basement collapse and in the results of Koumétio et al. [41], he suspected a collapse of the basement and intrusions of rocks buried in depths ranging from 3 to $18 \mathrm{~km}$ in this area;

- The following models profiles $\mathrm{P}_{1}, \mathrm{P}_{2}, \mathrm{P}_{3}$ and $\mathrm{P}_{4}$ suggest the presence of granite rocks and sedimentary rocks in the locality of Banyo and Abong-Mbang. Also, gneiss intrusions of volcanic rocks in the locality of Tibati, and granitic intrusions and basaltic rocks in the locality of Yoko. In the work of Noutchogwe [4], he suspected the presence of basaltic rocks, gneiss, granite and sediments in this area, especially in Adamawa;

- Models of profiles $\mathrm{P}_{5}, \mathrm{P}_{6}, \mathrm{P}_{7}, \mathrm{P}_{8}, \mathrm{P}_{9}, \mathrm{P}_{10}$ and $\mathrm{P}_{11}$ suggest that the study area could contain granite rocks and sedimentary intrusions that extend to the Djerem basin; sedimentary intrusions at Abong-Mbang, Yokaduma, Nanga-Eboko; gneissic formations near Meiganga and granito-basaltic formations in the localities of Bertoua and Belabo. The results of Noutchogwe [4] suggest an evolution of magma in relatively superficial "chambers", between base rocks separated by faults and both the presence of rocks such as Gneiss, granite, sediments, basalt, observed from residual anomalies.

When we make the comparison between the negative anomalies of long wavelengths observed and the topography of the study area, characterized by an average altitude of $1100 \mathrm{~m}$, the first idea that comes to mind about the origin of this anomaly is that of the isostatic compensation, which would have been affected by the sinking of the crust in the heavier upper mantle. However, seismological studies by Dorbath et al. [2] and Stuart et al. [42] have shown that the thickness of the crust is normal $(33 \mathrm{~km})$ in Adamawa and more reduced $(23 \mathrm{~km})$ when moving north. The same work also revealed the existence of an abnormally light structure in the upper mantle between 80 and $140 \mathrm{~km}$. These results corroborate the gravimetric work carried out by Poudjom-Djomani [3] then Poudjom-Djomani et al. [6] who suggested a thin lithosphere under the Adamawa, following a lighter asthenospheric ascent of about $40 \mathrm{~km}$. The great negative anomaly of Adamawa was therefore attributed to the resulting bulge while the zone of positive anomaly, narrower and centered on the plateau, is attributed on one hand to the thin crust and on the other hand, to the existence of non-flush magmatic pockets (Noutchogwe [4].

\section{Conclusions}

Analysis of Bouguer's anomaly map of his transformed maps and profiles made it possible to conclude that: 
- Rocks with density contrasts between -0.205 and $-0.19 \mathrm{~g} / \mathrm{cm}^{3}$ could be sedimentary and granitic, and these are observed in the localities of Banyo, Tignere, Ngaoundere and Abong-Mbang;

- Rocks with density contrasts between 0.052 and $0.0534 \mathrm{~g} / \mathrm{cm}^{3}$ could be gneiss, observed in the localities of Tibati, Sangbe as well in the NgaoundereNgaoundal region and the rocks with density contrasts between 0.285 and $0.29 \mathrm{~g} / \mathrm{cm}^{3}$ could be forming basalt rocks, observed in the localities of Belabo, Bertoua and in regions such as Sangbe-Yoko, Yoko-Abong-Mbang, Ndokayo and Yassem;

- In regions such as Sangbe-Yoko, Yoko-Abong-Mbang, Ngaoundere-Ngaoundal, Belabo, Bertoua-Abong-Mbang where the sediment densities are almost zero, one could think in this case of a dominance of high density rocks like basalt and Gneiss or a collapse.

The geophysical characterization of the gravimetric body in the study area integrates the results of gravimetric interpretations. The regional-residual separation of the Bouguer anomalies allowed us to establish a map of residual gravity anomalies essentially reflecting the gravitational effect of the sources found in the upper crust. The geological and tectonic context of the study area, located in the fault zone of the Cameroon Shear Center, allowed us to identify these intrusive bodies with basalts from the Cameroon Volcanic Line.

\section{Conflicts of Interest}

The authors declare no conflicts of interest regarding the publication of this paper.

\section{References}

[1] Ngako, V., Jegouzo, P. and Nzenti, J.P. (1991) Le Cisaillement Centre Camerounais. Rôle structural et géodynamique dans l'orogenèse panafricaine. Comptes rendus de P Académie des Sciences, Paris, 313, 457-463.

[2] Dorbath, L., Dorbath, C.W. and Fairhead, J.D. (1984) Structure de la croûte sous le plateau de l'Adamaoua (Cameroun). Comptes rendus de P Académie des Sciences, 298, 539-542.

[3] Poudjom-Djomani, Y.H. (1993) Apport de la gravimétrie à l'étude de la lithosphère continentale et implications géodynamiques: étude d'un bombement intaplaque: Le massif de l'Adamaoua (Cameroun). Thèse de Doctorat, Université de Paris Sud, Centre d'Orsay, $294 \mathrm{p}$.

[4] Noutchogwe, T.C. (2004) Apport de la gravimétrie à l'étude de la bordure méridionale du plateau de l'Adamaoua (Cameroun). Thèse de Doctorat 3e Cycle, Université de Yaoundé I, Yaoundé, $127 \mathrm{p}$.

[5] Kande, H.L. (2008) Étude géophysique de la structure de la croûte le long du fossé tectonique de la Mbéré (Sud Adamaoua-Cameroun). Thèse de Doctorat, Université de Yaoundé I, Yaoundé, 120.

[6] Poudjom-Djomani, Y.H., Nnange, J.M., Diament, M., Ebinger, C.J. and Fairhead, J.D. (1995) Effective Elastic Thickness and Crustal Thickness Variations in West Central African Ferried from Gravity Data. Journal of Geophysical Research, 100, 
22047-22070. https://doi.org/10.1029/95JB01149

[7] Ngatchou, H.E., Liu, G., Tabod, C.T., Kamguia, J., Nguiya, S., Tiedeu, A. and Ke, X. (2014) Crustal Structure beneath Cameroon from egm2008. Journal of Geodesy and Geodynamics, 5, 1-7. https://doi.org/10.3724/SP.J.1246.2014.01001

[8] Guiraudie, C. (1955) Carte géologique de reconnaissance à l'échelle du 1/500 000. Feuille Ngaoundéré-Ouest avec notice explicative. Direction des Mines et de la Géologie, Du Cameroun, 23 p.

[9] Lasserre, M. (1961) Étude géologique de la partie orientale de l'Adamaoua (Cameroun Central) et les principales sources minéralisées de l'Adamaoua. Bulletin of Direction des Mines et de la Géologies du Cameroun, 4, 130.

[10] Soba, D. (1989) La sériee du Lom: Étude géologique et géochronologique d'un basin volcano-sédimentaire de la chaîne panafricaine de l'Est du Cameroun. Thèse de Doctorat d'Etat, University of Paris VI, Paris, $181 \mathrm{p}$.

[11] Ngako, V. (1999) Les déformations continentales panafricaines en Afrique Centrale. Résultat d'un poinçonnement de type himalayéen. University of Yaoundé I, Yaoundé, 241.

[12] Nzenti, J.P., Barbey, P. and Tchoua, F.M. (1999) Evolution crustale au Cameroun: éléments pour un modèle géodynamique de l'orogenèse néoprotérozoïque. In: Vicat, J.P. and Bilong, P., Eds., Géologie et environnements au Cameroun, 397-407.

[13] Ngnotué, T., Nzenti, J.P., Barbey, P. and Tchoua, F.M. (2000) The Ntui-Betamba High-Grade Gneisses in Cameroon. Journal of African Earth Sciences, 31, 369-381. https://doi.org/10.1016/S0899-5362(00)00094-4

[14] Toteu, S.F., Van Schmus, R.W., Penaye, J. and Michard, A. (2001) New U-Pb and Sm-Nd Data from North-Central Cameroon and Its Bearing on the Pre-Pan-African History of Central Africa. Precambrian Research, 108, 45-73. https://doi.org/10.1016/S0301-9268(00)00149-2

[15] Kapajika, B. (2003) Les granites calco-alcalins de l'Ouest de Tibati dans la chaîne panafricaine Nord-équatoriale au Cameroun. Pétrogenèse et structurogenèse. Thèse de Doctorat, Université de Lubumbashi, République démocratique du Congo, $114 \mathrm{p}$.

[16] Temdjim, R. (1986) Le volcanisme de la region de Ngaoundéré (Adamaoua-Cameroun). Etude volcanologique et pétrographique. Thèse de Doctorat, Université Clermont-Ferrand, $185 \mathrm{p}$.

[17] Dautria, J.M. and Girod, M. (1986) Les enclaves de lherzolite à spinelle et plagiocles du volcan de Dibi (Adamaoua, Cameroun): Des témoins d'un manteau supérieur anormal. Bulletin of Minéral, No. 109, 275-288.

https://doi.org/10.3406/bulmi.1986.7934

[18] Nono, A., Déruelle, B., Demaiffe, D. and Kambou, R. (1994) Tchabal Nganha Volcano in Adamawa (Cameroon): Petrology of a Continental Alkaline Lava Series. Journal Volcanology Geothermal Research, 60, 147-178. https://doi.org/10.1016/0377-0273(94)90066-3

[19] Menard, J.J., Wandji, P., Déruelle, B. and Ezangono Tolo, J.M. (1998) Le volcan de Djinga (Adamaoua-Cameroun), géologie et pétrographie. In: Vicat, J.P. and Bilong, P., Éds., Géosciences au Cameroun, Press Université de Yaoundé I, Yaoundé, 169-184.

[20] Ateba, B., Dorbath, C., Dorbath, L., Ntepe, N., Frogneux, M., Aka, T.F., Hell, J.V., Delmond, J.C. and Manguelle-Dicoum, E. (2009) Eruptive and Earthquake Activities Related to the 2000 Eruption of Mount Cameroon Volcano (West Africa). Journal of Volcanology and Geothermal Research, 179, 206-216. https://doi.org/10.1016/j.jvolgeores.2008.11.021 
[21] Déruelle, B., Ezangono, J., Lissom, J., Ngnotué, N., Ngounouno, I., Nkoumbou, C., Nono, A. and Simo, E. (1987) Moi-Pliocène Basaltic Lava Flows and Phonolitic and Trachytic Plugs North and East of Ngaoundere (Adamaoua, Cameroon). In: Matheis, E. and Schandelmeir, A., Eds., Current Research in African Earth Sciences, Balkema, Rotterdam, 261-264.

[22] Nnangue, J.M., Ngako, V., Fairhead, J.D. and Ebinger, C.J. (2000) Depths to Density Discontinuities beneath the Adamawa Plateau Region, Central Africa, from Spectral Analyses of New and Existing Gravity Data. Journal of African Earth Sciences, 30, 887-901. https://doi.org/10.1016/S0899-5362(00)00058-0

[23] Dorbath, L., Dorbath, C., Fairhead, J.D. and Stuart, G.W. (1986) A Teleseismic Delay Time Study across the Central African Shear Zone in the Adamawa Region of Cameroon, West Africa. Geophysical Journal, Royal Astronomical Society, 86, 751-766. https://doi.org/10.1111/j.1365-246X.1986.tb00658.x

[24] Ayonghe, S.N. (1983) Interpretation of a Gravity Profile across the Ngaoundéré Rift (Cameroon) and Comparison with Existing Gravity Data. University of Leeds, Leeds, 121.

[25] Plomerova, J., Babuska, V., Dorbath, C., Dorbath, L. and Lillie, J.R. (1993) Deep Lithospheric Structure across the Central African Shear Zone in Cameroon. Geophysical Journal International, 115, 381-390. https://doi.org/10.1111/j.1365-246X.1993.tb01193.x

[26] Dumort, J.F. (1986) Identification par télédétection de l'accident de la Sanaga (Cameroun). Sa position dans le contexte des grands accidents d'Afrique Centrale et de la limite nord du craton Congolais. Géodynamique, 1, 13-19.

[27] Nzenti, J.P., Njanko, T., Njiosseu, E.L. and Tchoua, F.M. (1998) Les domaines granulitiques de la chaîne panafricaine nord-equatoriale au Cameroun. Géologie et Environnement au Cameroun, Collection Geocam, 1, 255-264.

[28] Toteu, S.F., Penaye, J. and Poudjom, Y.D. (2004) Geodynamic Evolution of the Pan-African Belt in Central Africa with Special Reference to Cameroon. Canadian Journal of Earth Sciences, 41, 73-85. https://doi.org/10.1139/e03-079

[29] Ngako, V., Affaton, P., Nnange, J.M. and Njanko, T. (2003) Pan-African Tectonic Evolution in Central and Southern Cameroon: Transpression and Transtension during Sinistral Shear Movements. Journal of African Earth Sciences, 36, 207-214. https://doi.org/10.1016/S0899-5362(03)00023-X

[30] Ngangom, E. (1983) Etude tectonique du fossé de la Mbéré et du Njerem, Sud Adamaoua. Bulletin des Centres de Recherches Exploration-Production Elf-Aquitaine, 7, 339-347.

[31] Popoff, M. (1988) Du Gondwana à l'Atlantique Sud: Les connexions du fossé de la Bénoué avec les bassins du NE brésilien jusqu'à l'ouverture du golfe de Guinée au Crétacé inférieur. Journal of African Earth Sciences Special Issues, 7, 409-431. https://doi.org/10.1016/0899-5362(88)90086-3

[32] Cornacchia, M. and Dars, R. (1983) Un trait structural majeur du continent Africain. Les linéaments centrafricains du Cameroun au Golfe d'Aden. Bulletin de la Société Géologique de France, 25, 101-109. https://doi.org/10.2113/gssgfbull.S7-XXV.1.101

[33] Dumort, J.F. (1987) Etude structurale des bordures Nord et Sud du plateau de l'Adamaoua: Influence du contexte atlantique. Géodynamique, 2, 55-68.

[34] Temdjim, R. and Tchoua, F.M. (1999) Etude de l'altération palagonitique dans les hyaloclastites du district volcanique de Ngaoundéré (Nord-Cameroun). Géologie et environnements au Cameroun, GEOCAM, 2, 285-292. 
[35] Eyike, A. and Ebbing, J. (2014) Lithospheric Structure of the West and Central African Rift System from Regional Three-Dimensional Gravity Modeling. South African Journal of Geology, 118, 285-298. https://doi.org/10.2113/gssajg.118.3.285

[36] Radhakrishna, M.I.V. and Krishnamacharyulu, S.K.G. (1990) Polyfit: A Fortran 77 Program to Fit a Polynomial of Any Order to Potential Field Anomalies. Journal of the Association of Exploration Geophysicists, 11, 99-105.

[37] Talwani, M. and Ewing, M. (1960) Rapid Computation of Gravitational Attraction of 3-Dimensional Bodies of Arbitrary Shape. Geophysics, 25, 203-225. https://doi.org/10.1190/1.1438687

[38] Darly, R.A. (1966) Handbook of Physical Constants. Geological Society of America, Memoir, 97.

[39] Sydney, P. and Clark, J. (1966) Handbook of Physical Constants. Geological Society of America, Memoir, 97.

[40] Telford, W.M., Geldart, L.P. and Keys, D.A. (1976) Applied Geophysics. Cambridge University Press, Cambridge, 860 p.

[41] Koumetio, F., Njomo, D., Noutchogwe, C.T., Kamga Tokam, A.P., Tabod, C. and Manguelle Dicoum, E. (2014) Interpretation of Gravity Anomalies by Multi-Scale Evaluation of Maxima of Gradients and 3D Modelling in Bipindi Region (SouthWest Cameroon). International Journal of Geosciences, 5, 1415-1425. https://doi.org/10.4236/ijg.2014.512115

[42] Stuart, G.W., Fairhead, J.D., Dorbath, L. and Dorbath, C. (1985) A Seismic Refraction Study of the Crustal Structure Associated with the Adamawa Plateau and Garoua Rift, Cameroon, West Africa. Geophysics Journal Royal Astronomical Society, 81, 1-12. https://doi.org/10.1111/j.1365-246X.1985.tb01346.x 